\title{
IN QUEST OF SUFFICIENT EQUIVALENCE. POLISH AND ENGLISH INSOLVENCY TERMINOLOGY IN TRANSLATION. A COMPARATIVE STUDY ${ }^{1}$
}

\begin{abstract}
The paper deals with the problem of translating selected insolvency terminology from Polish into English and from English into Polish. The research corpora encompassed the Insolvency Act 1986 (England and Wales) as amended and Ustawa z dnia 28 lutego 2003. Prawo upadtościowe $i$ naprawcze [the Act on Polish Insolvency and Rehabilitation Law of $28^{\text {th }}$ February 2003 as amended]. The research methods included: (i) the comparison of parallel texts, (ii) the method of axiomatisation of the legal linguistic reality, (iii) the terminological analysis of the corpus material, (iv) the concept of adjusting the target text to the communicative needs and requirements of the community of recipients and (v) the techniques of providing equivalents for non-equivalent terminology. The research hypothesis has been so formulated that the parametrisation of legal reality may assist in finding more adequate equivalents and determine differences in meaning of compared source and target language terms, which in turn facilitates the choice of a more adequate technique of providing equivalents for non-equivalent or partially equivalent legal terminology meeting the communicative needs of translation recipients. The research results revealed that insolvency terminology is highly system-bound and available equivalents may often be misleading for the community of target text recipients.
\end{abstract}

Keywords: axiomatisation, parametrisation, insolvency terminology, source and target language terms.

The paper deals with the problem of translating insolvency terminology from Polish into English and from English into Polish. The terminology relating to insolvency law is extremely system-bound ${ }^{2}$ and in many communicative situations requires the translator to resort to techniques of providing equivalents for non-equivalent or partially equivalent terminology (cf. Matulewska, 2007, Kubacki, 2012) in order to convey the source text message successfully. The problem results from the fact that the legal systems of Poland and Great Britain differ significantly. Poland is one of the 


\section{Aleksandra Matulewska}

so-called civil law countries (countries situated in the territory of the European continent, where the Roman legal system was adopted through the Napoleonic codifications). In Great Britain, especially England and Wales, the evolution of the legal system was different and the so-called common law developed there. It should be borne in mind that there is no single legal system of Great Britain. One actually may distinguish the legal systems of (i) England and Wales, (ii) Scotland and (iii) Northern Ireland. It is also worth mentioning that The Isle of Man and Jersey, Guernsey and also Sark are still subject to the English crown though they have, at least to a certain extent, their own legislation and courts. Consequently, there is no single jurisdiction in the UK. There are separate statutory instruments enacted for those three jurisdictions (sometimes even for England and Wales separate acts of law are enacted). It should also be remembered that in the course of history as a result of antagonisms between England and Scotland, the Scots formerly educated themselves in law in France rather than England. As a result of that Scots law is a mixture of elements of Roman law and common law. What is typical of the Scottish and Irish legal systems is the fact that they differ in respect to legal terminology used. For instance as far as personal insolvency law is concerned Scots use terms including 'sequestration', 'Accountant in Bankruptcy', 'Commissioners' etc. and Irishmen use 'personal insolvency arrangement', 'Committee of Dáil Éireann', 'specified creditor', 'inspector', etc. which are not used in English insolvency law. The Scottish legal terminology may, in some circumstances analogously to the legal terminology used for instance in the State of Louisiana (which is also derived from Roman law), be a source of functional equivalents for Polish legal terminology due to the adoption of the Roman legal code in those three jurisdictions. Poland and Louisiana adopted Roman law primarily from the Napoleonic Code whereas Scotland adopted the so-called Roman-Dutch law.

Due to those complex legal divergences and resultant terminological differentiation the term 'English' will be used in this paper to refer to the insolvency terminology used in England and Wales only.

Currently numerous problems arise due to the fact that English is the language used internationally for communication and that it is gaining dominance over the other languages in the European Union. Therefore, some problems arise in connection with the interpretation of English terminology in the light of a given legal system to which a given term refers (cf. Rayar, 1992; Smith, 1995; Kielar, 1996; Alcaraz, Varó \& Hughes, 2002; Mattila, 2006; Cao, 2007; Galdia, 2009; Goddard, 2009 and others). Numerous factors should be considered starting from the fact that the English language is the official language in over sixty countries around the world and further- 
more the fact that it is the official language of various international institutions. This results in problems with determining the meaning of a given term used in the source text, which in fact is a prerequisite for finding sufficient equivalents in the target language for the purpose of translation.

\section{Research hypothesis}

The research hypothesis, which has been proposed is as follows: the parametrisation of legal reality may help determine differences in meaning of the compared source and target language terms and find more adequate equivalents. As a consequence such parametrisation process helps select a proper technique of providing equivalents for non-equivalent or partially equivalent legal terminology. In order to select a proper technique of providing equivalents one must consider the communicative needs of translation recipients. If the needs and requirements of communicative recipients are fulfilled in respect to the conveyance of the informative contents of the source text message by the application of a given technique, then the technique may be accepted as proper. Consequently, the technique is proper only for a specific communicative community of recipients, at a particular time and in a given communicative situation.

\section{Research corpora}

The research corpora encompassed two statutory instruments, being the statute in force in England and Wales titled Insolvency Act 1986 (England and Wales) as amended and the statute in force in Poland titled: Ustawa $z$ dnia 28 lutego 2003. Prawo upadłościowe $i$ naprawcze [the Act on Polish Insolvency and Rehabilitation Law of 28 ${ }^{\text {th }}$ February 2003] as amended. Both Acts comprehensively regulated the insolvency law in both territories. It should be remembered, however, that in England and Wales there are also other statutory instruments, which may be relevant in the case of analyses of other insolvency terminology. Those include the so-called Insolvency Rules. Since, the analysis described in this paper referred to key terminology (selected names of insolvency procedures) it was not necessary to refer to those other statutory instruments.

\section{Research methods}

Research methods applied comprise the following:

(i) the comparison of parallel texts,

(ii) the method of axiomatisation of the legal linguistic reality, 


\section{Aleksandra Matulewska}

(iii) the terminological analysis of the corpus consisting of the two statutory instruments mentioned above,

(iv) the concept of adjusting the target text to the communicative needs and requirements of the community of recipients and finally

(v) the techniques of providing equivalents for non-equivalent or partially equivalent terminology.

The method of comparison of comparable texts (formerly called parallel texts e.g. by Neubert, 1996; Delisle et al., 1999) is currently considered to be one of the basic tools at the disposal of translators; as such texts are a source of not only terminological but also phraseological (collocational) and grammatical information. Thus, they serve the purpose of establishing text-pragmatic equivalence (cf. Kierzkowska, 2002). There are numerous papers on the usefulness of such texts (cf. Kubacki, 2013; Roald \& Whittaker, 2010; Neubert, 1996). Neubert (1996:101) stresses that:

Parallel texts are texts produced by users of different languages under nearidentical communicative conditions. [...] Parallel text files [...] are an element and entirety of the material and mental equipment of the competent translator. This equipment is a vast database storing enormous experience. It is the key to an extensive knowledge of how texts are structured in the (text) world of different (communicative) cultures.

It should also be mentioned here that in some works the differentiation has been recently made between 'parallel texts' and 'comparable texts'. Roald and Whittaker (2010:95) use the term parallel texts to refer to various language versions of the same legal instrument (e.g. in the context of multiple language versions of EU legislation). In some older works the term parallel texts is used in that context by for instance Šarčević (2000:21). For the purpose of this study let us invoke the definition provided by Delisle et al. (1999:166) in accordance with which a parallel text is "a text that represents the same text type as the source text" or "a text that treats the same or a closely related topic in the same subject field and that serves as a source for the «mots justes» and «terms» that should ideally be incorporated into the «target text» to ensure collocational «cohesion»."

For the purpose of this paper it is assumed that comparable texts are texts belonging to the same legal genre formulated in two different languages. As the source text and its translation into another language is not analysed, the term comparable texts shall be used to refer to the analysed statutory instruments being: the Insolvency Act 1986 as amended (England and Wales) and Ustawa $z$ dnia 28 lutego 2003. Prawo 
upadtościowe i naprawcze [the Act on Polish Insolvency and Rehabilitation Law of $28^{\text {th }}$ February 2003 as amended].

The method of axiomatisation of legal linguistic reality assumes parametrisation of legal reality objects in order to be able to compare them for the purpose of rendering successful legal translation (Matulewska, 2013a).

The terminological analysis of the corpus consisted in excerpting key terms referring to types of proceedings regulated by the statutory instruments in question. Their statutory definitions were found and other typical features on the basis of pertinent literature (books on the topic written by academics dealing with insolvency law in Poland and England) were determined. Having established the meaning of selected terms, the comparison of Polish and English terminology was undertaken in order to discover to what extent they are convergent and divergent. In order to do so the method of parametrisation of legal terminology (Bańczerowski \& Matulewska, 2012; Matulewska, 2013a) has been applied. The dimensions in respect to which the terms are convergent ${ }^{3}$ have been distinguished. In relation to dimensions in respect to which the terms have been shown to be divergent, the analysis was intended to reveal whether the relation of complementarity is maintained between two terms in question.

When two terms are sufficiently convergent it is assumed that the relation of near equivalence is maintained between them. If they are permissibly complementary then the relation of partial equivalence exists between them. And if none of those relations holds, then the relationship between the two terms is one of the so-called non-equivalence. The terms near, partial and non-equivalence are used after Šarčević (2000:238-239), according to whom near equivalence is the case

when concepts A and B share all of their essential and most of their accidental characteristics (intersection) or when concept A contains all of the characteristics of concept B, and concept B all of the essential and most of the accidental characteristics of concept A (inclusion) [...]. In the majority of cases functional equivalents are only partially equivalent. Partial equivalence occurs when concepts A and B share most of their essential and some of their accidental characteristics (intersection) or when concept A contains all of the characteristics of concept B but concept B only most of the essential and some of the accidental characteristics of concept A (inclusion). [...] If only a few or none of the essential features of concepts A and B coincide (intersection) or if concept A contains all of the characteristics of concept B but concept B only a few or none of the essential features of concept A (inclusion), then the functional equivalent can no longer be considered acceptable. In such cases, one speaks of non-equivalence. Furthermore, non-equivalence also occurs in cases where there is no functional equivalent in the target legal system for a particular source concept. In such cases one speaks of exclusion. 


\section{Aleksandra Matulewska}

The concept of adjusting the target text to the communicative needs and requirements of the community of recipients presupposes that there are various communicative communities (cf. Zabrocki, 1963; Bańczerowski, 2001) with various communicative needs. The problem of adjusting a translation product to the needs of recipients has been discussed not only in general translation studies (e.g. Vermeer's theory of skopos cf. Vermeer, 2001) but also in legal translation studies (e.g. Šarčević, 2000; Kierzkowska, 2002; Jopek-Bosiacka, 2010 and others). At present it is an undeniable fact that different communicative communities have differing communicative needs and need a different level of translation accuracy (in terms of providing them with more or less detailed information concerning legal system differences). Additionally, there are numerous cases in which not-conveying the sufficient level of information led to harmful or undesirable consequences affecting translation recipients and system of justice (cf. Berk-Seligson, 1999; Winter, 2012).

The techniques of providing equivalents for non-equivalent or partially equivalent terminology have already been discussed for several decades (cf. Vinay \& Darbelnet, 1966; Newmark, 1982, 1988, 1991; Kierzkowska, 2002; Matulewska, 2007; Kubacki, 2012). When looking for equivalents the following techniques may be considered:

(i) different types of borrowings:

- loanwords,

- loanblends,

- loanshifts (calques),

- hybrids,

- exotics,

- international terms,

(ii) definitions and other types of descriptive equivalents,

(iii) neologisms,

(iv) expansion,

(v) restriction,

(vi) two terms or more for one,

(vii) cultureless descriptive and Latin-based terms,

(viii) unassimilated Latin terms,

(ix) functional equivalents,

(x) modified functional equivalents, and

(xi) antonyms.

but not all of them have been applied to the terminology in question. ${ }^{4}$ That is due to the fact that a limited number of terms have been discussed here and the techniques, which have been used include descriptive equivalents and modified functional equivalents. 
In Quest of Sufficient Equivalence. Polish and English Insolvency...

\section{Research results of a comparative study of Polish and English insolvency terminology}

In general under Polish law one may distinguish two types of insolvency proceedings and one type of rehabilitation proceedings. Each insolvency proceeding commences the moment the court declares insolvency. The stage between filing a winding-up petition and declaring insolvency is preliminary as it may end with dismissal of the proceedings or with the declaration of insolvency. Depending on the petition the court may declare insolvency either ending with the liquidation of the insolvent debtor's estate or open to arrangement with creditors. The insolvency open to arrangement with creditors may end either in the liquidation of the insolvent debtor's estate or with the restructuring of debts and keeping the enterprise as a going concern.

When the petition for the declaration of insolvency is filed the so-called postepowanie $w$ przedmiocie ogłoszenia upadłości begins. When the conditions provided for the declaration of insolvency are met (the debtor is insolvent, but his estate is sufficient to cover at least the costs of insolvency proceedings) the court issues an order in which it declares insolvency. Depending on what the petitioner has pleaded for, two types of insolvency proceedings may be instigated that is to say: the proceedings to liquidate the insolvent debtor's estate, called in the Polish language postępowanie upadłościowe likwidacyjne ['insolvency proceedings in which the debtor's estate is to be liquidated'] ${ }^{5}$ (articles 306-360 of the Act on Polish Insolvency and Rehabilitation Law of $28^{\text {th }}$ February 2003 as amended) and the proceedings intended to save the enterprise of the debtor by making an arrangement with creditors concerning the repayment of debts called in turn postępowanie upadłościowe z możliwościa zawarcia układu ['insolvency proceedings in the course of which the debtor may make an arrangement with the creditors concerning the mode of the satisfaction of the debtor's debts'] (articles 267-305 of the Act on Polish Insolvency and Rehabilitation Law of $28^{\text {th }}$ February 2003 as amended). The latter type of proceedings may end with the liquidation of the insolvent business, as the priority of the proceedings is to satisfy the creditors to the greatest extent possible. It should be borne in mind, however, that both types of proceedings in their course might be converted into the other type. When postępowanie w przedmiocie ogłoszenia upadtości ['proceeding to have the insolvency of the debtor declared'] starts, the insolvency practitioner called tymczasowy nadzorca sadowy ['provisional court supervisor'] is appointed. In the event of instigating postępowanie upadłościowe likwidacyjne the in- 


\section{Aleksandra Matulewska}

solvency practitioner called syndyk is appointed (articles 173-179 of the Act on Polish Insolvency and Rehabilitation Law of $28^{\text {th }}$ February 2003 as amended), and for postępowanie upadłościowe z możliwościa zawarcia uktadu the practitioner appointed is nadzorca sadowy ['court supervisor'] (articles 180-181 of the Act on Polish Insolvency and Rehabilitation Law of $28^{\text {th }}$ February 2003 as amended). The third type of proceedings called postęowanie naprawcze ['rehabilitation proceedings, restructuring proceedings, reconstruction proceedings'] is intended to save the enterprise of the debtor by making an arrangement with creditors concerning the restructuring of the business and satisfaction of debts, before the debtor becomes insolvent to an extent making it impossible to save the business as a going concern. In this type of proceedings the insolvency practitioner appointed is nadzorca sadowy. As postepowanie naprawcze does not seek the liquidation of the insolvent debtor's estate but is to help restructure his debts and save the company before it becomes insolvent it shall not be discussed here in more detail (articles 492-521 of the Act on Polish Insolvency and Rehabilitation Law of $28^{\text {th }}$ February 2003 as amended) (cf. also Jakubecki \& Zedler, 2003; Zedler, 2004).

In England and Wales one may distinguish two types of proceedings, depending on the type of the debtor, being:

(i) personal insolvency

(ii) corporate insolvency

Personal insolvency is applicable to debtors who are individuals (natural persons) and who are unable to pay their debts when they fall due (Keay \& Walton, 2003:38). Corporate insolvency in turn is applicable to companies, which are unable to pay their debts when they fall due (Keay \& Walton, 2003:40-43).

Taking into account the object of the proceedings, one may distinguish three types of proceedings:

(i) winding up or bankruptcy

(ii) provisional liquidation

(iii) non-terminal insolvency

There are two types of proceedings available to individuals, that is to say:

(i) bankruptcy and

(ii) individual voluntary arrangement (IVA).

Bankruptcy is a terminal process, which ends with liquidation. It is regulated by sections 264-371 of the Insolvency Act 1986 as amended. "Bankruptcy is the process to which an individual may be made subject, where his or her debts are so overwhelming as to be incapable of being 
paid in full as and when they are due. The process begins with the petition to the court for bankruptcy order." (Keay \& Walton, 2003:38; cf. also Rajak, 1991:109; Marsh, 2004). First the debtor or his creditors must file a bankruptcy petition, next the court issues a bankruptcy order and the proceeding called bankruptcy starts then. The trustee in bankruptcy is appointed for the bankrupt debtor (Tolmie, 1998:152-155). There are the following stages of the procedure:

(i) filing the petition for bankruptcy,

(ii) giving a bankruptcy order, which actually is the commencement of bankruptcy,

(iii) liquidation of the debtor's estate,

(iv) dissolution.

The debtor wishing to start the IVA regulated under the Insolvency Act 1986 sections 252-263 must prepare a proposal concerning repayment of debts in instalments, file a petition for an interim order and have a nominee of a voluntary arrangement appointed. The nominee becomes the supervisor of the IVA the moment the interim order is given by the court and the IVA starts (Tolmie, 1998:67-81; Keay \& Walton, 2003:155-167).

As far as companies are concerned the proceedings may be terminal proceedings called winding up, and non-terminal insolvency proceedings such as receivership, administrative receivership, administration and company voluntary arrangement.

There are also the following types of non-terminal insolvencies

(i) company voluntary arrangement

(ii) receivership and administrative receivership

(iii) administration

(iv) other arrangements (e.g. London approach) (Keay \& Walton, 2003)

As one may see from the juxtaposition presented above, there are more types of insolvency proceedings in England and Wales than in Poland. What stems directly from that is the fact that Polish and English insolvency terminology is system-bound.

Winding up may be either compulsory (winding up by the court) or voluntary. Voluntary winding up may be instigated by the company itself and then it is called members' voluntary winding up or by creditors and then it is called creditors' voluntary winding up. Part IV sections 73-219 and Part V sections 220-229 regulate those proceedings for registered and unregistered companies respectively. Analogously to bankruptcy the procedure has the following stages

(i) filing the winding-up petition,

(ii) winding-up order given by the court - commencement of winding up, 


\section{Aleksandra Matulewska}

(iii) liquidation of the company,

(iv) dissolution of the company (striking the company out of registers).

After the presentation of a winding-up petition until the moment when the compulsory winding-up order is given by the court, the person appointed is the provisional liquidator. He performs functions conferred on him by the court. The insolvency practitioner appointed in that type of proceedings is called liquidator. In the case of voluntary winding-up the liquidator is responsible for collecting, realising and distributing company's assets and sometimes managing the company. In the event that the compulsory winding-up is instigated, he carries out functions conferred on him by the court. If neither the debtor nor creditors choose a liquidator, the proceedings are called compulsory winding-up and the court appoints an official receiver, who acts as a liquidator being responsible for securing that the assets of the company are gathered, realised and distributed to the company's creditors and, if there is surplus, to the persons entitled to it (Keay \& Walton, 2003:191-298).

The company or corporate voluntary arrangement (CVA) is instigated for companies and is an equivalent of the IVA. It is intended to save the company by making an arrangement with creditors concerning the repayment of debts. It is regulated by Part I of the Insolvency Act 1986 as amended, sections 1-7B. After the presentation of the petition for CVA, the nominee of a company voluntary arrangement is appointed. He is responsible for reporting to court that a meeting of creditors and shareholders should be convened in order to vote for the proposal. When the court gives an order in which it approves the CVA, the nominee becomes the supervisor of a company voluntary arrangement being responsible for carrying out all necessary tasks in the course of the company voluntary arrangement. CVA and winding up may be converted into one another, analogously to IVA and bankruptcy (Keay \& Walton, 2003:126-154).

Administration, receivership and administrative receivership are procedures concerning the protection of interests of secured creditors. They have no equivalents in the Polish legal system as the term zarzad ['management'] used in the Polish insolvency law differs too much from the English terms in question. Consequently, the translator in such a situation is required to 'coin' equivalents with the use of techniques of providing equivalents for non-equivalent terminology. However, due to the limited scope of this paper and the complexity of the meaning of those terms, they will not be discussed here in more detail. The problem of translating the names of those procedures and insolvency practitioners appointed in them into Polish requires a separate article. 
Now one may compare (i) winding up, bankruptcy and postępowanie upadtościowe likwidacyjne. The parametrisation of these three terms in question is presented in Table 1.

Table 1

\section{Parametrisation of the terms: winding up, bankruptcy and postępowanie upadłościowe likwidacyjne}

\begin{tabular}{|c|c|c|c|c|}
\hline & & & Term & \\
\hline & Dimension & winding up & bankruptcy & $\begin{array}{l}\text { postępowanie } \\
\text { upadtościowe } \\
\text { likwidacyjne }\end{array}$ \\
\hline 1. & $\begin{array}{l}\text { the author of the } \\
\text { text }\end{array}$ & legislator & legislator & legislator \\
\hline 2. & text delivery form & written & written & written \\
\hline 3. & text status & binding & binding & binding \\
\hline 4. & $\begin{array}{l}\text { the time of text } \\
\text { creation }\end{array}$ & valid & valid & valid \\
\hline 5. & $\begin{array}{l}\text { branch of law to } \\
\text { which the text } \\
\text { refers to }\end{array}$ & insolvency law & insolvency law & insolvency law \\
\hline 6. & text genre & a statute & a statute & a statute \\
\hline 7. & $\begin{array}{l}\text { the language of the } \\
\text { text }\end{array}$ & English & English & Polish \\
\hline 8. & text legal reality & common law & common law & civil law \\
\hline 9 . & $\begin{array}{l}\text { text language } \\
\text { variety }\end{array}$ & $\begin{array}{l}\text { British English } \\
\text { (England and } \\
\text { Wales) }\end{array}$ & $\begin{array}{l}\text { British English } \\
\text { (England and } \\
\text { Wales) }\end{array}$ & not applicable \\
\hline 10. & $\begin{array}{l}\text { object of the } \\
\text { proceedings }\end{array}$ & $\begin{array}{l}\text { liquidation of the } \\
\text { insolvent debtor's } \\
\text { estate and satisfac- } \\
\text { tion of creditors to } \\
\text { the greatest extent } \\
\text { possible }\end{array}$ & $\begin{array}{l}\text { liquidation of the } \\
\text { insolvent debtor's } \\
\text { estate and satisfac- } \\
\text { tion of creditors to } \\
\text { the greatest extent } \\
\text { possible }\end{array}$ & $\begin{array}{l}\text { liquidation of the } \\
\text { insolvent debtor's } \\
\text { estate and satisfac- } \\
\text { tion of creditors to } \\
\text { the greatest extent } \\
\text { possible }\end{array}$ \\
\hline 11. & $\begin{array}{l}\text { person who may file } \\
\text { a petition }\end{array}$ & $\begin{array}{l}\text { the insolvent } \\
\text { debtor, the in- } \\
\text { solvent debtor's } \\
\text { creditors }\end{array}$ & $\begin{array}{l}\text { the insolvent } \\
\text { debtor, the in- } \\
\text { solvent debtor's } \\
\text { creditors }\end{array}$ & $\begin{array}{l}\text { the insolvent } \\
\text { debtor, the in- } \\
\text { solvent debtor's } \\
\text { creditors }\end{array}$ \\
\hline 12. & $\begin{array}{l}\text { person for whom } \\
\text { the proceedings } \\
\text { may be instigated }\end{array}$ & $\begin{array}{l}\text { legal person (com- } \\
\text { pany) }\end{array}$ & $\begin{array}{l}\text { natural person (an } \\
\text { individual includ- } \\
\text { ing a partner in } \\
\text { a partnership) }\end{array}$ & $\begin{array}{l}\text { any type of per- } \\
\text { son (including both } \\
\text { legal and natural } \\
\text { persons conducting } \\
\text { business activity) }\end{array}$ \\
\hline
\end{tabular}




\section{Aleksandra Matulewska}

The main difference between winding up and bankruptcy is the fact that the former is instigated for companies (legal persons) and the latter for natural persons who may conduct some business in the form of a partnership. The Polish postępowanie upadłościowe likwidacyjne may be instigated for both types of insolvent debtors, that is to say legal and natural persons. Therefore, for the dimension 12 having three parameters/properties (legal person, natural person, any type of person) the terms assume different properties. The relation of convergence holds between terms in question in respect of dimensions 1-6 and 10-11 and the relation of complementarity holds in respect of dimensions 7 and 12. The relation of divergence holds between two English terms and the Polish one in respect to dimension 9. Therefore, if one examines equivalents suggested by TEPIS (Polish Society of Sworn and Specialised Translators) (Kierzkowska, 1996 with subsequent updates), the Publishing House Zakamycze (Świerk-Bożek, 2003) and the Publishing House C. H. Beck (Bińkowska, Niemirska-Fido \& Walawender, 2010), which published translations of the Polish Insolvency and Rehabilitation Act 2003, one needs to take into account that difference in meaning. Additionally, one should remember that the English language, as already mentioned, is used in many jurisdictions (over 60 countries around the world 6 ).

Thus, legal translators need to consider at least the American and EU usage of insolvency terminology when translating from Polish into English. In the American legal system the term bankruptcy is used to refer to the phenomenon, which in the United Kingdom and the European Union is called insolvency. Therefore, the equivalents suggested by TEPIS bankruptcy proceedings including liquidation of bankrupt's assets, Zakamycze bankruptcy proceedings involving liquidation of bankrupt's assets and C. H. Beck bankruptcy by liquidation of the debtor's assets are descriptive equivalents modifying the term bankruptcy, which in reference to the communicative community of American recipients would convey the meaning of the Polish term whereas in the event of translating for the English communicative community would suggest that the proceedings are applicable only to natural persons. When one considers the EU usage, the term would be winding-up proceedings, which means "insolvency proceedings within the meaning of point (a) involving realising the assets of the debtor, including where the proceedings have been closed by a composition or other measure terminating the insolvency, or closed by reason of the insufficiency of the assets" (Regulation no. 1346 on Insolvency proceedings, article 1(c)). It should be borne in mind that the EU terminologists frequently use signs used in the common law system but modify their meaning to fit the civil (continental Europe) legal systems. Thus, none of the three 
translations of the Polish Act into English is oriented toward the EU usage. Thus, if translating for a communicative community of close recipients (cf. Kierzkowska, 2002) who need more details on legal system differences it may be better to provide a descriptive equivalent based on the EU terminology, which to some extent is considered an international usage at least for the recipient from the EU and use winding up for natural and legal persons or modify the term bankruptcy by adding that the Polish procedure is applicable to both natural and legal persons. In turn, when translating the English terms bankruptcy and winding up into the Polish language one may modify the functional Polish equivalent informing about the type of person to whom such a procedure applies e.g. postępowanie upadtościowe likwidacyjne dla osób fizycznych (w tym spótek osobowych) and postępowanie upadłościowe likwidacyjne dla osób prawnych (spółek kapitałowych) respectively. Such equivalents reveal the difference in the meaning of terms in question in respect to dimension 12. If one wishes to reveal the difference resulting from the relation of complementarity holding in respect to dimensions 7 and 12 one would need to add a reference to a legal system, in which the institution functions e.g. postępowanie upadłościowe likwidacyjne dla osób fizycznych (w tym spótek osobowych) w Anglii $i$ Walii and postępowanie upadtościowe likwidacyjne dla osób prawnych (spótek kapitałowych) w Anglii $i$ Walii respectively for the terms bankruptcy and winding up.

The analysis of the meaning of the following terms: liquidator, trustee in bankruptcy and syndyk their parametrisation is presented in Table 2.

As far as the dimension 12 has three parameters/properties, all three terms assume different properties (are complementary in respect to dimension 12). The relation of convergence holds between terms in question in respect of dimensions $1-6$ and 10 . The relation of complementarity holds in respect of dimensions $7,8,11,12$ and 13 . The relation of divergence holds between two English terms and the Polish one in respect to dimension 9. The Polish insolvency practitioner appearing in that type of proceedings is called syndyk, which TEPIS (Kierzkowska, 1996 with subsequent updates) translates as a bankruptcy estate trustee, Zakamycze (Świerk-Bożek, 2003) and C. H. Beck (Bińkowska, Niemirska-Fido \& Walawender, 2010) as a trustee, both of which are modified functional equivalents. None of the translations uses the EU term liquidator. It may be due to the fact that the term liquidator in the EU context is translated into Polish as zarzadca (polysemy and intertextuality of the term zarzadca has been discussed in Matulewska, 2013b) Therefore, as far as the dimension 12 having three parameters/properties (legal person, natural person, any type of person) the terms assume different properties. The relation of convergence holds between terms in question in 
Table 2

Parametrisation of the terms: liquidator, trustee in bankruptcy and syndyk

\begin{tabular}{|c|c|c|c|c|}
\hline & \multirow[b]{2}{*}{ Dimension } & \multicolumn{3}{|c|}{ Term } \\
\hline & & liquidator & $\begin{array}{l}\text { trustee in } \\
\text { bankruptcy }\end{array}$ & syndyk \\
\hline 1. & $\begin{array}{l}\text { the author of the } \\
\text { text }\end{array}$ & legislator & legislator & legislator \\
\hline 2. & text delivery form & written & written & written \\
\hline 3. & text status & binding & binding & binding \\
\hline 4. & $\begin{array}{l}\text { the time of text } \\
\text { creation }\end{array}$ & valid & valid & valid \\
\hline 5. & $\begin{array}{l}\text { branch of law to } \\
\text { which the text } \\
\text { refers to }\end{array}$ & insolvency law & insolvency law & insolvency law \\
\hline 6. & text genre & a statute & a statute & a statute \\
\hline 7. & $\begin{array}{l}\text { the language of the } \\
\text { text }\end{array}$ & English & English & Polish \\
\hline 8. & text legal reality & common law & common law & civil law \\
\hline 9. & $\begin{array}{l}\text { text language } \\
\text { variety }\end{array}$ & $\begin{array}{l}\text { British English } \\
\text { (England and } \\
\text { Wales) }\end{array}$ & $\begin{array}{l}\text { British English } \\
\text { (England and } \\
\text { Wales) }\end{array}$ & not applicable \\
\hline 10. & responsibilities & $\begin{array}{l}\text { collecting, realis- } \\
\text { ing and distributing } \\
\text { insolvent debtor's } \\
\text { assets and some- } \\
\text { times managing the } \\
\text { business }\end{array}$ & $\begin{array}{l}\text { collecting, realis- } \\
\text { ing and distributing } \\
\text { insolvent debtor's } \\
\text { assets and some- } \\
\text { times managing the } \\
\text { business }\end{array}$ & $\begin{array}{l}\text { collecting, realis- } \\
\text { ing and distributing } \\
\text { insolvent debtor's } \\
\text { assets and some- } \\
\text { times managing the } \\
\text { business }\end{array}$ \\
\hline 11. & $\begin{array}{l}\text { person for whom } \\
\text { the insolvency } \\
\text { practitioner is } \\
\text { appointed }\end{array}$ & $\begin{array}{l}\text { legal person } \\
\text { (company) }\end{array}$ & $\begin{array}{l}\text { natural person (an } \\
\text { individual includ- } \\
\text { ing a partner in } \\
\text { a partnership) }\end{array}$ & $\begin{array}{l}\text { legal and natural } \\
\text { persons conducting } \\
\text { business activity }\end{array}$ \\
\hline 12. & $\begin{array}{l}\text { procedure or stage } \\
\text { of the procedure }\end{array}$ & $\begin{array}{l}\text { winding up: liqui- } \\
\text { dation by (a) vol- } \\
\text { untary winding up } \\
\text { and (b) compulsory } \\
\text { winding up by the } \\
\text { court (see below) }\end{array}$ & bankruptcy & $\begin{array}{l}\text { insolvency pro- } \\
\text { ceedings (after } \\
\text { the declaration of } \\
\text { insolvency) with } \\
\text { the intention of } \\
\text { liquidation }\end{array}$ \\
\hline 13. & $\begin{array}{l}\text { institution appoint- } \\
\text { ing the insolvency } \\
\text { practitioner }\end{array}$ & $\begin{array}{l}\text { the insolvent debtor } \\
\text { or creditors }\end{array}$ & $\begin{array}{l}\text { the insolvent debtor } \\
\text { or creditors }\end{array}$ & the court \\
\hline
\end{tabular}


respect of dimensions 1-6 and 10-11 and the relation of complementarity holds in respect of dimensions 7 and 12. The relation of divergence holds between two English terms and the Polish one in respect to dimension 9. Additionally, it may be considered a 'false friend' as under the Polish Code of Commercial Partnerships and Companies there is a person designated as the likwidator, who is responsible for realising the company's assets when the company is being liquidated (not necessarily as a result of it becoming insolvent). Nevertheless, it seems necessary to inform close recipients (e.g. lawyers) that a bankruptcy trustee in Poland is appointed for natural and legal persons. Analogously when translating the term liquidator and trustee in bankruptcy in reference to the English insolvency law into Polish one should consider using the following modified functional equivalent: syndyk dla osób prawnych and syndyk dla osób fizycznych (przedsiębiorców bedacych osobami fizycznymi) respectively. If one wishes to reveal the difference resulting from the relation of complementarity holding in respect to dimension 7, 12 and 13 one would need to add a reference to a legal system, in which the institution functions and the appointing institution e.g. syndyk dla osób fizycznych (w tym spótek osobowych) w Anglii $i$ Walii powolywany przez dtużnika lub wierzycieli and syndyk dla osób prawnych (spótek kapitałowych) $w$ Anglii $i$ Walii powolywany przez dtuznika lub wierzycieli respectively for the terms trustee in bankruptcy and liquidator.

Finally, the parametrisation of the following terms company (corporate) voluntary arrangement (CVA), individual voluntary arrangement (IVA) and postępowanie upadłościowe z możliwościa zawarcia uktadu is presented in Table 3.

Therefore, insofar as the dimension 12 having three parameters/properties (legal person, natural person, any type of person) the terms assume different properties. The relation of convergence holds between terms in question in respect of dimensions 1-6 and 10-11 and the relation of complementarity holds in respect of dimensions 7 and 12 . The relation of divergence holds between two English terms and the Polish one in respect to dimension 9. Consequently, as far as the IVA, CVA and postepowanie upadłościowe $z$ możliwościa zawarcia uktadu are concerned similar information should be added when translating for the communicative community of close recipients. Thus, the equivalents for the Polish term suggested by TEPIS (bankruptcy proceedings open to arrangement), Zakamycze (bankruptcy with the possibility of concluding a reorganisation) and C. H. Beck (bankruptcy with a possibility to make an arrangement) should be supplemented with the information concerning the fact that the term bankruptcy is used in reference to both natural and legal persons. When translating the IVA and 


\section{Aleksandra Matulewska}

Table 3

Parametrisation of the terms: company (corporate) voluntary arrangement (CVA), individual voluntary arrangement (IVA) and postępowanie upadtościowe z możliwościa zawarcia uktadu

\begin{tabular}{|c|c|c|c|c|}
\hline & \multirow[b]{2}{*}{ Dimension } & \multicolumn{3}{|c|}{ Term } \\
\hline & & $\begin{array}{c}\text { company (corporate) } \\
\text { voluntary arrange- } \\
\text { ment (CVA) }\end{array}$ & $\begin{array}{c}\text { individual voluntary } \\
\text { arrangement } \\
\text { (IVA) }\end{array}$ & $\begin{array}{l}\text { postepowanie upadto- } \\
\text { ściowe z możliwościa } \\
\text { zawarcia uktadu }\end{array}$ \\
\hline 1. & $\begin{array}{l}\text { the author of the } \\
\text { text }\end{array}$ & legislator & legislator & legislator \\
\hline 2. & text delivery form & written & written & written \\
\hline 3. & text status & binding & binding & binding \\
\hline 4. & $\begin{array}{l}\text { the time of text } \\
\text { creation }\end{array}$ & valid & valid & valid \\
\hline 5 . & $\begin{array}{l}\text { branch of law to } \\
\text { which the text } \\
\text { refers to }\end{array}$ & insolvency law & insolvency law & insolvency law \\
\hline 6. & text genre & a statute & a statute & a statute \\
\hline 7. & $\begin{array}{l}\text { the language of the } \\
\text { text }\end{array}$ & $\begin{array}{l}\text { British English } \\
\text { (England and } \\
\text { Wales) }\end{array}$ & $\begin{array}{l}\text { British English } \\
\text { (England and } \\
\text { Wales) }\end{array}$ & Polish \\
\hline 8. & text legal reality & common law & common law & civil law \\
\hline 9. & $\begin{array}{l}\text { text language } \\
\text { variety }\end{array}$ & $\begin{array}{l}\text { British English } \\
\text { (England and } \\
\text { Wales) }\end{array}$ & $\begin{array}{l}\text { British English } \\
\text { (England and } \\
\text { Wales) }\end{array}$ & not applicable \\
\hline 10. & $\begin{array}{l}\text { aim of the proceed- } \\
\text { ings }\end{array}$ & $\begin{array}{l}\text { either restructur- } \\
\text { ing the insolvent } \\
\text { company's debts or } \\
\text { liquidation of the } \\
\text { insolvent company's } \\
\text { estate in order to } \\
\text { satisfy creditors to } \\
\text { the greatest extent } \\
\text { possible }\end{array}$ & $\begin{array}{l}\text { either restructur- } \\
\text { ing the insolvent } \\
\text { debtor's debts or } \\
\text { liquidation of the } \\
\text { insolvent debtor's } \\
\text { estate in order to } \\
\text { satisfy creditors to } \\
\text { the greatest extent } \\
\text { possible }\end{array}$ & $\begin{array}{l}\text { either restructur- } \\
\text { ing the insolvent } \\
\text { debtor's debts or } \\
\text { liquidation of the } \\
\text { insolvent debtor's } \\
\text { estate in order to } \\
\text { satisfy creditors to } \\
\text { the greatest extent } \\
\text { possible }\end{array}$ \\
\hline 11. & $\begin{array}{l}\text { person who may file } \\
\text { a petition }\end{array}$ & $\begin{array}{l}\text { the insolvent } \\
\text { debtor, the in- } \\
\text { solvent debtor's } \\
\text { creditors }\end{array}$ & $\begin{array}{l}\text { the insolvent } \\
\text { debtor, the in- } \\
\text { solvent debtor's } \\
\text { creditors }\end{array}$ & $\begin{array}{l}\text { the insolvent } \\
\text { debtor, the in- } \\
\text { solvent debtor's } \\
\text { creditors }\end{array}$ \\
\hline 12. & $\begin{array}{l}\text { person for whom } \\
\text { the proceedings } \\
\text { may be instigated }\end{array}$ & $\begin{array}{l}\text { legal person } \\
\text { (company) }\end{array}$ & $\begin{array}{l}\text { natural person (an } \\
\text { individual includ- } \\
\text { ing a partner in } \\
\text { a partnership) }\end{array}$ & $\begin{array}{l}\text { legal and natural } \\
\text { persons conducting } \\
\text { business activity }\end{array}$ \\
\hline
\end{tabular}


CVA into Polish in turn one may again use modified functional equivalents (i) postępowanie upadłościowe dla osób fizycznych z możliwościa zawarcia uktadu and postępowanie upadłościowe dla osób prawnych z możliwościa zawarcia uktadu revealing the difference in meaning in respect to dimension 12 respectively or (ii) postępowanie upadtościowe dla osób fizycznych $z$ możliwościa zawarcia uktadu w systemie common law $w$ Anglii $i$ Walii and postępowanie upadłościowe dla osób prawnych z możliwościa zawarcia uktadu $w$ systemie common law $w$ Anglii $i$ Walii revealing the divergence in meaning in respect to dimension 9 and complementarity in respect to dimensions 7 and 8 respectively.

\section{Concluding remarks}

In conclusion, legal system differences make the process of legal translation challenging. The more divergent legal systems are, the more systembound terminology problems may occur in the process of translation. Legal translation is performed to fulfil specific communicative needs of persons involved in legal communication process. Such persons may have different educational backgrounds, different qualifications, knowledge and communicative needs. The task of the translator is strictly connected with the fact that he/she acts as an intermediary in interlingual and interlegal communication (Kierzkowska, 2011). He/she should be the expert in conveying the message in a manner adjusted to the needs and requirements of community of recipients. This in turn involves finding an answer to the following questions: How to translate term $X$ from the source language into the target language? What are the differences in the meaning of term $X$ used in the source language in comparison with a potential equivalent functioning in the target language? What is the minimally required part of the meaning of term $X$ used in the source language that must be conveyed when translating it into the target language? In general, one must realise that translation and interpreting in legal settings may require the translator or interpreter to resort not only to interlingual translation or interpreting but also intralingual renderings. If the translation or interpreting is rendered for persons not well versed in law it may be necessary not only to find an equivalent for a given term but also to explain its meaning in colloquial language to make the process of interlingual communication successful.

The parametrisation of terminology enables the establishment of differences in meaning and provides information on the extent to which terms are convergent, complementary or divergent. Insolvency law is a specific branch 


\section{Aleksandra Matulewska}

of law, which an ordinary man or woman in another profession rarely has contact with. Thus, in the majority of cases the translations of texts dealing with insolvency are rendered for the communicative community of close recipients (e.g. businessmen who are insolvent or their creditors as well as companies' shareholders or lawyers). Such persons are interested in legal system differences. It will be frequently necessary to supplement modified functional equivalents or descriptive equivalents with exotics (direct borrowings from the source language preserving the spelling of the term). None of the analysed translations of the Polish insolvency statute actually revealed the essential differences in meaning and all of them may be misleading for the translation recipient. This may indicate that the hypothesis put forward at the beginning of the paper may find confirmation. However, the author realises that it must be verified on the basis of a larger terminological corpus. Nevertheless, the method obliges translators and terminologists to consider the essential elements of the meaning of terms, which are to be translated.

There is also a need for a consciously 'coined' and balanced equivalent as in practice the translator makes decisions intuitively (on the spot). The choice of relevant dimensions is in fact subjective as well as depending on information, to which the translator has access, while rendering a specific translation. It should depend, however, on the communicative needs of the community of recipients. Excessively lengthy descriptive equivalents are on many occasions cumbersome and impede comprehension of the text. Therefore, the translator should avoid, if possible, lengthy descriptive equivalents with an encyclopaedic volume of explanation. At the same time short descriptive or functional equivalents may result in misunderstandings and may make the communication process ineffective as a result of distortions of meaning (omitting some vital information). This in turn may give target text recipients an exaggerated and misleading impression of similarity to their own legal system. It should also be borne in mind that there is an unlimited number of communicative communities, which may require the help of a translator as an intermediary in the process of communication in legal settings. The problem of providing equivalents is especially tricky when one must consider a group of diversified translation recipients, e.g. participants of an international conference devoted to some legal issues whose education, jurisdiction, mother tongues, communicative skills, etc. differ. This issue, however, has been addressed in more detail in Matulewska (2013a). The problem also arises when one is unable to parametrise the community of translation recipients due to the lack of information about target text recipients (which is often the case when the translator works for a transla- 
tion agency, which does not wish to reveal the identity of the translation commissioner).

To sum up, the needs of the translation recipient community shall be a determining factor when choosing an equivalent or a technique of providing equivalents as in legal settings the change of the meaning may have farreaching consequences. Thus, determining whether one translates for a close or distant or self-determined recipient is a prerequisite for the proper choice of equivalents, which should convey the meaning sufficient for the proper understanding of the message by a specific communicative community.

\section{N O T E S}

1 The research financed from the research grant no. 2012/07/E/HS2/00678, titled: Parametrization of legilinguistic translatology in the scope of civil law and civil procedure awarded by the National Science Centre of the Republic of Poland (Sonata Bis program).

2 System-bound terms 'designate concepts and institutions peculiar to the legal reality of a specific system or related systems' (Sarčević, 2000:233).

3 "In general, in order for two texts $T_{i}$ and $T_{j}$ to be translationally convergent in respect to a given dimension, both texts must take on the same property from a given dimension. If two texts $T_{i}$ and $T_{j}$ take on different properties from a given dimension, they are translationally complementary relative to this dimension. If two texts $T_{i}$ and $T_{j}$ take on different properties from a given dimension, and take on the same property from a more abstract but not too abstract hyper-dimension, then they are permissibly complementary." (Matulewska, 2013a:63).

4 The techniques listed above have been applied when researching a wider array of terms and communicative communities of translation recipients in Matulewska (2013a).

${ }^{5}$ Descriptions provided in square brackets are not treated as equivalents here but are provided for better understanding of the meaning of discussed terms. However, in some cases they may be equivalents for the Polish terms.

6 "Only a few centuries ago, the English language consisted of a collection of dialects spoken mainly by monolinguals and only within the shores of a small island. Now it includes such typologically distinct varieties as pidgins and creoles, new Englishes, and a range of differing standard and non-standard varieties that are spoken on a regular basis in more than 60 different countries around the world (Crystal, 1985). English is also, of course, the main language used for communication at an international level." (Cheshire, 1994b:1)

\section{R E F E R E N C E S}

Alcaraz Varó, E. \& Hughes, B. (2002). Legal Translation Explained. Manchester. S. Jerome Publishing.

Bańczerowski, J. \& Matulewska, A. (2012). Towards the Foundations of Legilinguistic Translatology. In P. Grzegorczyk, K. Knoppek \& M. Walasik (Eds.), Proces cywilny. Nauka-Kodyfikacja-Praktyka. Ksiega jubileuszowa dedykowana Profesorowi Feliksowi Zedlerowi (pp. 1225-1261). Warszawa: Wolters Kluwer Polska. 


\section{Aleksandra Matulewska}

Bańczerowski, J. (2001). The Linguistic Legacy of Ludwik Zabrocki. In St. Puppel (Ed.), The Ludwik Zabrocki Memorial Lecture (pp. 9-49). Poznań: Adam Mickiewicz University.

Berk-Seligson, S. (1999). The impact of court interpreting on the coerciveness of leading questions. In International Journal of Speech Language and the Law, vol. 6, No. 1(1999).

Cao, D. (2007). Translating Law. Clevedon: Multilingual Matters Ltd.

Cheshire, J. (Ed.). (1994). English around the World. Sociolinguistic Perspectives. Cambridge: Cambridge University Press.

Crystal, D. (1985). How Many Millions? The Statistics of English Today. English Today 1, pp. 7-11.

Delisle J. et al. (Eds.) (1999). Translation Terminology. Amsterdam/Philadephia: John Benjamins Publishing Company.

Galdia, M. (2009). Legal Linguistics. Frankfurt am Main: Peter Lang Publishing House.

Goddard, Ch. (2009). Where Legal Cultures Meet: Translating Confrontation into Coexistence. Investigationes Linguisticae vol. XVII, 168-205.

Jackob, J. I. H. (1995). Atkin's Encyclopaedia of Court Forms in Civil Proceedings. Volume 10. Companies - Winding-up. London: Butterworths.

Jakubecki, A., Zedler, F. (2003). Prawo upadtościowe i naprawcze. Komenatrze Zakamycza. Kraków: Zakamycze.

Jopek-Bosiacka, A. (2010). Legal Communication: A Cross-Cultural Perspective. Warsaw: Warsaw University Press.

Keay, A., Walton, P. (2003). Insolvency Law: Corporate and Personal. London: Pearson Education Limited.

Kielar, B. Z. (1996). Na manowcach tłumaczenia tekstu prawnego: prawdopodobieństwo wywołania szoku kulturowego. In F. Grucza \& K. Chomicz-Jung (Eds.), Problemy komunikacji interkulturowej. Jedna Europa - wiele języków i wiele kultur (pp. 135-141). Warszawa: Wydawnictwo Uniwersytetu Warszawskiego.

Kierzkowska, D. (2002). Ttumaczenie prawnicze. Warszawa: Wydawnictwo TEPIS.

Kierzkowska, D. (Ed.) (2011). Kodeks Tłumacza Przysiegłego z komentarzem. Warszawa: Wydawnictwo Translegis.

Kubacki, A. D. (2012). Tłumaczenie poświadczone. Status, kształcenie, warsztat $i$ odpowiedzialność tłumacza przysiegłego. Warszawa: Wolters Kluwer Business.

Kubacki, A. D. (2013). Teksty paralelne jako narzędzie pomocnicze przy sporządzaniu tłumaczeń specjalistycznych. Comparative Legilinguistics 20013/13, $137-148$.

Marsh, D. (2004). Bankruptcy, Insolvency and the Law. A Comprehensive Guide to All Aspects of Bankruptcy and Insolvency. Revised Edition. Brighton: Easyway Guides. 
Mattila, H. (2006). Comparative Legal Linguistics. England: Ashgate.

Matulewska, A. (2007). Lingua Legis in Translation. Frankfurt am Main, Germany: Peter Lang Publishing House.

Matulewska, A. (2013a). Legilinguistic Translatology. A Parametric Approach to Legal Translation. Frankfurt am Main, Germany: Peter Lang Publishing House.

Matulewska, A. (2013b). Polska terminologia prawa upadłościowego w kontekście. Przekład terminu zarządca na język angielski. Comparative Legilinguistics 20013/13, pp. 149-162.

Neubert, A. (1996). Textlinguistics of Translation: The Textual Approach to Translation. In R. M. Gaddis (Ed.), Translation Horizons Beyond the Boundaries of Translation Spectrum. Translation Perspectives IX (pp. 87-105). Binghamton: Center for Research in Translation.

Newmark, P. (1982). Approaches to Translation. Oxford: Pergamon Press Ltd.

Newmark, P. (1988). A Textbook of Translation. UK: Prentice Hall International Ltd.

Newmark, P. (1991). About Translation. Clevedon: Multilingual Matters Ltd.

Rajak, H. (1991). Insolvency Law. Theory and Practice. London: Sweet \& Maxwell.

Rayar, L. (1992). Translating Law: Method or Madness? In J. Miler (Ed.), International Forum of Legal Translation 1992. Proceedings (pp. 62-71). Warszawa: Wydawnictwo TEPIS.

Roald J. \& Whittaker S. (2010). Verbalization in French and Norwegian Legislative Texts: A Contrastive Case Study. In M. Gotti \& Ch. Williams (Eds.), Legal Discourse Across Languages and Cultures. Linguistic Insights 117 (pp. 95107). Bern: Peter Lang.

Šaračević, S. (2000). New Approach to Legal Translation. The Hague: Kluwer Law International.

Smith, S. A. (1995). Culture Clash: Anglo-American Case Law and German Civil Law in Translation. In M. Morris (Ed.), Translation and the Law (pp. 181-197). American Translators Association Scholarly Monograph Series, vol. VIII, 1995. Amsterdam/Philadelphia: John Benjamins Publishing Company.

Tolmie, F. (1998). Introduction to Corporate and Personal Insolvency Law. London: Sweet \& Maxwell.

Vermeer, H. J. (2001). Skopos and Commission in Translational Action. In L. Venuti \& M. Baker (Eds.), The Translation Studies Reader (pp. 221-232). London, New York: Routlege.

Vinay, J. P. \& Darbelnet J. (1966). Stylistique comparée du français et de l'anglais. Paris: Didier.

Winter, R. J. (2012). What did he say? Mistranslations in the court. In: Judicial Notebook. Retrieved July 2013 from http://www.apa.org/monitor/2012/03/ jn.aspx. 


\section{Aleksandra Matulewska}

Zabrocki, L. (1963). Wspólnoty komunikatywne $w$ genezie i rozwoju jezzyka niemieckiego. Część I. Prehistoria języka niemieckiego. Wrocław, Warszawa, Kraków: Zakład Narodowy imienia Ossolińskich Wydawnictwo Polskiej Akademii Nauk.

Zedler, F. (2004). Prawo upadtościowe i naprawcze w zarysie. Kraków: Zakamycze.

\section{Translations of the Polish Act into English}

Bińkowska, M., Niemirska-Fido K. \& Walawender R. A. (2010). The Bankruptcy and Reorganisation Law. Prawo upadtościowe i naprawcze. Warszawa: C. H. Beck.

Kierzkowska, D. (Ed.) (1996). Polish Law Collection. Warsaw: Wydawnictwo TEPIS with subsequent supplements.

Świerk-Bożek, K. (2003). Law on Bankrutcy and Rehabilitation. Prawo upadtościowe $i$ naprawcze. Kraków: Zakamycze.

\section{Source texts}

Rozporządzenie Rady (WE) nr 1346/2000 z dnia 29 maja 2000 r. w sprawie postępowania upadłościowego. Retrieved June 2013 from Eur-Lex http://eurlex.europa.eu/LexUriServ/LexUriServ.do?uri=OJ:L:2000:160:0001:0018:pl: PDF.

Insolvency Act 1986. Retrieved June 2013 from HMS government website: http: //www.insolvency.gov.uk/insolvencyprofessionandlegislation/legislation/uk /insolvencyact.pd.

The European Council Regulation (EC) No 1346/2000 on insolvency proceedings. Retrieved June 2013 from Eur-Lex http://eur-lex.europa.eu/LexUriServ/Lex UriServ.do?uri=OJ:L:2000:160:0001:0018:en:PDF.

Ustawa z dnia 28 lutego 2003. Prawo upadłościowe i naprawcze. Retrieved June 2013 from the website of Kancelaria Sejmu http://isap.sejm.gov.pl/Details Servlet?id=WDU20030600535.

Ustawa z dnia 15 września 2000 r. Kodeks spółek handlowych [Polish Code of Commercial Partnerships and Companies]. Retrieved June 2013 from the website of Kancelaria Sejmu http://isap.sejm.gov.pl/DetailsServlet?id=WDU 20000941037. 